[7] Філософський енциклопедичний словник : энциклопедия [Текст] / НАН України, Ін-т філософії ім. Г. С. Сковороди ; голов. ред. В. І. Шинкарук. - Київ : Абрис, 2002. - 742 с.

[8] Гринів О. І. Філософія: курс лекцій для аспірантів / О. І. Гринів. - Львів : Тріада плюс, 2016. - 364 с.

\title{
References
}

[1] Dychkivska, I. M. Innovatsiini pedahohichni tekhnolohii [Innovative pedagogical technologies] (2015), Akademvydav, Kiev, 304 p (In Ukrainian).

[2] Atanov, G.A., Pustynnikova I.N. Obuchenie i iskusstvennyy intellekt, ili Osnovy sovremennoy didaktiki vysshey shkoly [Training and Artificial Intelligence, or Basics of Modern Higher School Didactics] (2002), Izd-vo DOU, Donetsk, 504 p (In Russian).

[3] Atanov., G.A. Deyatel'nostnyy podhod v obuchenii [Activity approach in training] (2001), EAI-pres, Donetsk , $180 \mathrm{p}$ (In Russian).

[4] Zudina E.V. Pedagogicheskaya innovatika v upravlenii personalom obrazovatel'noy organizacii: zadachi i varianty ispol'zovaniya [Pedagogical Innovation in Personnel Management of an Educational Organization: Tasks and Uses] (2016), Elektronnyy nauchno-obrazovatel'nyy zhurnal VGSPU «Grani poznaniya», № 2 (45), pp. 8 - 15(In Russian).

[5] Shliakhy realizatsii kredytno-modulnoi systemy orhanizatsii navchalnoho protsessu i testovykh form kontro-liu znan studentiv - materialy naukovo-metodychnoho seminaru [Ways of realization of credit-module system of organization of educational process and test forms of student knowledge control - materials of scientific and methodical workshop] (2011) Orhanizatsiia ta standartyzatsiia navcha-lnoho protsesu ,vyd-vo «Astroprynt», Odesa, Vol.5,111 p.

[6] Shemshuchenko, Yu. S. Yurydychna entsyklopediia: v 6 t.[ Law Encyclopedia: 6 tons.] (2011),NAN Ukrainy; In-t derzh. i prava im. V. M. Koretskoho, Yurydychna dumka,. T. 1: A-H. , pp. 142-143(In Ukrainian).

[7] Shynkaruk , V. I. Filosofskyi entsyklopedychnyi slovnyk : antsyklopedyia [Philosophical Encyclopedia Dictionary: Encyclopedia] (2002), NAN Ukrainy, In-t filosofii im. H. S. Skovorody, Abrys, Kiev, 742 p (In Ukrainian).

[8] Hryniv, O. I. Filosofiia: kurs lektsii dlia aspirantiv [Philosophy: Lectures course for graduate students] (2016), Triada plius, Lviv, 364 p (In Ukrainian).

\section{IMPLEMENTATION OF A STANDARDIZED INFORMATION MANAGEMENT SYSTEM INTO ACTIVITY OF SCIENTIFIC AND TECHNICAL LIBRARY}

\author{
A.Bohdanov' ${ }^{1}$, V.M. Plotnikov' ${ }^{2}$ K.V. Smirnova ${ }^{3}$, I. I.Zinchenko ${ }^{4}$ \\ 1,2,3,4 Odessa National Academy of Food Technologies, Odessa, Ukraine \\ ORCID: ${ }^{20000-0001-9000-2568, ~}{ }^{3} 0000-0002-3818-8083$, \\ E-mail: ${ }^{1}$ bohdanov.artem97@gmail.com, ${ }^{2}$ vmplotnik@gmail.com, ${ }^{3}$ smirnova.kathrin@gmail.com, \\ ${ }^{4}$ libonaft@gmail.com
}

Copyright $(\mathcal{C} 2018$ by author and the journal "Automation technologies and business - processes.

This work is licensed under the Creative Commons Attribution International License (CC BY).

http://creativecommons.org/licanses/by/4.0

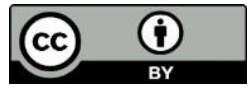

ONAFT

Open Access

DOI: 10.15673/atbp.v10i1.874

An effective solution to the tasks of preserving and accessing electronic documentation requires software applications, namely an electronic archive within the information management system of the organization. The information management system is a digital object-control and management system, as well as facilitates the planning and control functions of the 
http://www.atbp.onaft.edu.ua/

enterprise. The object of research is the information management system for the fund of the Scientific and Technical Library ONAFT. The main goal of this project is to create a single electronic resource, namely, an institutional repository for the conservation of scientific works, articles, media, patents, educational objects, annotations and dissertations that are freely available for both HIE employees and for the world the community

At present, information technology plays a key role in the process of obtaining, storing and disseminating information and knowledge, and is one of the most important tools for strategic development of libraries.

Modern software tools such as the IntelliJ IDEA Ultimate Edition development environment, the JavaEE specification, the Java programming language, the Spring framework, the Apache Maven and Apache Ant project assemblies, the Hibernate library, the PostgreSQL database management system, the query language, were used to create the software. SQL To play the institutional repository, the DSpace platform, which is an open source software, was used

The result of the development is the information and control system for the library fund STL ONAFT, implemented for the purpose of free access to research related to the development of a specific subject area, for further use in the educational process of HIE. The implemented software product is based on the established list of requirements for the functional capabilities of the project. During the development of the information management system for the library fund, the tasks were completed.

Keywords: web, web application, repository, information management system.

Для ефективного рішення задач збереження та доступу до електронної документації, необхідне прикладне програмне забезпечення, а саме електронний архів у складі інформаційно-управляючої системи організації. Інформаційно-управляюча система являє собою ичирову систему контролю та керування об'єктами, а також полегшує виконання функиій планування та контролю діяльності підприємства. Об'єктом дослідження являється інформаційно-управляюча система для фонду Науково-технічної бібліотеки ОНАХТ. Головною метою даного проекту є створення єдиного електронного ресурсу, а саме інституціийного репозиторію для збереження наукових працьь, статей, медіа матеріалів, патентів, учбових об'єктів, анотацій та дисертацій, які знаходяться у вільному доступі, як для співробітників ЗВО, так і для світової спільноти.

На даний момент інформаційні технологї виконують ключову роль у процесі отримання, збереження $i$ розповсюдження інформації та нових знань, становлять один з найважливіших інструментів стратегічного розвитку бібліотек.

Для створення програмного продукту були використані сучасні засоби розробки, такі як інтегроване середовище розробки IntelliJ IDEA Ultimate Edition, специфікація JavaEE, мова програмування Jаvа, фреймворк Sргіng, системи збірки проекту Apache Maven ma Apache Ant, бібліотека Hibernate, cuстема управління базами даних PostgreSQL, мова запитів SQL. Для відтворення інституційного репозиторію була використана платформа DSрасе, яка являє собою відкрите програмне забезпечення

Результатом розробки є інформачійно-управляюча система для бібліотечного фонду НТБ ОНАХТ, реалізована 3 метою вільного доступу до наукових досліджень пов'язаних з розвитком певної предметної галузі, для подальшого використання у навчальному процесі ЗВО. Реалізований програмний продукт є побудованим за сформованим переліком вимог до функиіональних можливостей проекту. Під час розробки інформаційно-управляючої системи для бібліотечного фонду було виконано поставлені завдання.

Ключові слова: веб, веб-додаток, репозиторій, інформаційно-управляюча система.

\section{Introduction}

An effective solution to the tasks of preserving and accessing electronic documentation requires software applications, namely an electronic archive within the information management system of the organization. The information management system is a digital object-control and management system, as well as facilitates the planning and control functions of the enterprise. The main tasks of the IMS are the preservation, processing, analysis, use, and protection of information. The main avocation of this system is to simplify the work of man, to correct major mistakes that arise during work and to increase the quality of work.

The object of research is the information management system for the fund of the Scientific and Technical Library ONAFT. At the moment, despite the development of information technologies, most scientific papers, articles, editions and educational materials are stored in paper format, which complicates the search for the necessary information. In order to facilitate the preservation, access and reproduction of information, an institutional repository was developed which is freely available.

\section{Problem statement}

At the present stage of development of Ukrainian science, the disciplines that are exploring informational activity occupy a prominent place, which is based on various documentary forms. In the first place, they include a bibliography, library science, bibliography, which are united in one scientific specialty, which allows to comprehensively consider the problems of the development of these scientific disciplines. Since the main objective of library activity is the formation of a library and information space, which involves the collective creation and use of shared resources, therefore, in today's conditions, there is 
http://www.atbp.onaft.edu.ua/

a need to strengthen the information interaction between libraries on the basis of promising information technologies and standards.

At present, information technology plays a key role in the process of obtaining, storing and disseminating information and knowledge, and is one of the most important tools for strategic development of libraries. Based on information technologies in libraries, new services and services are being developed, a new library environment is being created, staffing is being expanded. That is why the study and implementation of information technology in the work of libraries is one of the most important directions of modern library activity.

The electronic library, as an equal module of the information system, is directly interacting with the information repository. Getting the necessary information from the institutional repository software significantly reduces the number of library links required with the databases of the HIE departments.

\section{Purpose and objectives of the study}

The main goal of this project are to create a single electronic resource, namely, an institutional repository for the conservation of scientific works, articles, media, patents, educational objects, annotations and dissertations that are freely available for both HIE employees and for the world the community. To reproduce the set goal, a number of tasks were solved, namely:

- detected and investigated industry implementation;

- $\quad$ analyzed several existing analogues;

- $\quad$ selected methods and implementation environment;

- identification and elimination of probable deficiencies.

The object of research is the management information system for the library fund STL ONAFT. At the moment, despite the development of information technologies, most scientific papers, articles, editions and educational materials are stored in paper format, which complicates the search for the necessary information. In order to facilitate the preservation, access and reproduction of information, an institutional repository was developed which is freely available.

\section{Methods and materials of research}

To design the project, an integrated software development environment was chosen - IntelliJ IDEA, the object-oriented programming language was chosen in Java in the main language. The software was developed on the JavaEE platform, which is suitable for creating enterprise level applications. In developing the project, the automation tool for working with Apache Maven software projects was used to automate the assembly of the project based on their description of the structure in the POM files, and the Spring framework, which provides the solution to most tasks when developed on the JavaEE platform. A Hibernate library was also used to solve object-relational mapping tasks.

To play the institutional repository, the DSpace platform was used, which is an open source software written in the Java programming language. DSpace supports a large amount of data, and records themselves are available through a web resource.

For the development of the database of the information management system, a free object-relational database management system - PostgreSQL was used. This DBMS is based on the SQL language and supports most of the standards of this language. The main features of this DBMS are highly efficient and reliable transaction and replication mechanisms, an expanded system of embedded programming languages. The main features are functions, triggers, rules, views, and indexes.

The developed software, which is the information management system for the library fund, has a client/server application classification, the three-tier architecture of which consists of the client and server parts, a relational database was created to store and access data. The presented architecture organizes the separation of application level from data management. Separate a separate program level, which focuses on the application logic of the program. Data management is carried out by the data server.

The expanded interaction of the elements is depicted in the information scheme in Fig 1.

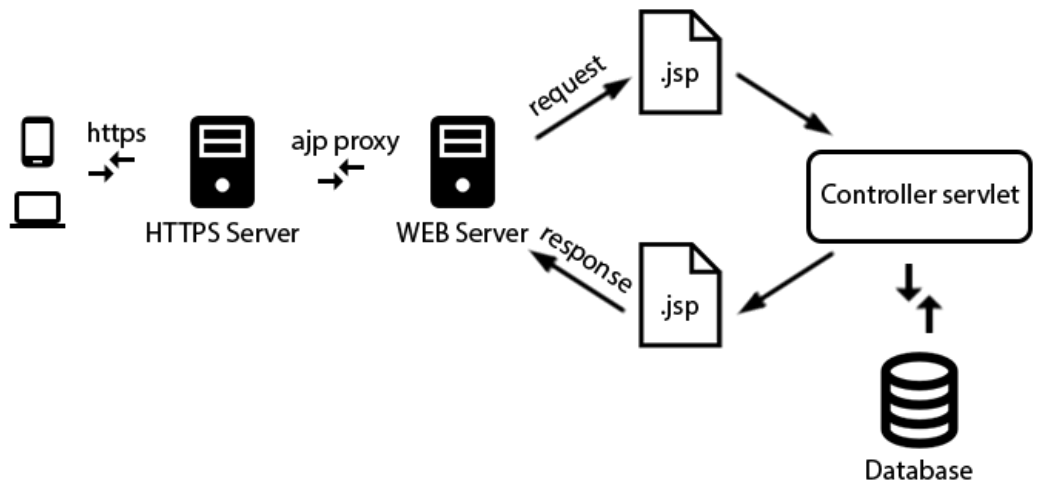

Fig. 1 - the information schema of web-application 
When a user requests a web application, the data is sent to the HTTP server via the https protocol. The server checks the domain name from the request through which it was contacted and sent through AJP protocol using the proxy tunnel to the Apache Tomcat web server. An Http server is required to distribute queries to several different web applications, since a software product, which is an information retrieval system of the institutional repository, is being deployed in the "ecosystem" of other software products of the ONAFT Scientific and Technical Library. Next, Apache Tomcat shares query with the web application. The server receives the request for any information, it is handled by the web application controller. If the request requires information from the database, then the controller accesses the DBMS, processes all the necessary information and returns the request to view the component as Java servlet pages of the file that is sent to the user.

\section{Research results}

The result of the development is the information and control system for the library fund STL ONAFT, implemented for the purpose of free access to research related to the development of a specific subject area, for further use in the educational process of HIE.

The developed software has a three-tier architecture. This architecture consists of a client, an application server, and a database management server. To interpret the created web resource, you need an application to view the created web page. The project is adaptive to various platforms, provides a multilingual interface that meets the modern requirements for a web resource.

To operate the system, there are several groups of users:

- main administrators are a group of users who have unrestricted rights to use the system's functionalities and distributes rights to other users for access to different levels;

- section administrators are a group of users who have unlimited rights within the specified section or sections;

- collections administrators are a group of users who have unlimited rights within a particular collection or collections;

- anonymous users - a group of users who have rights only to view sections, collections and their contents.

The system has an opportunity to subscribe to new collections. It's enough to be registered in the

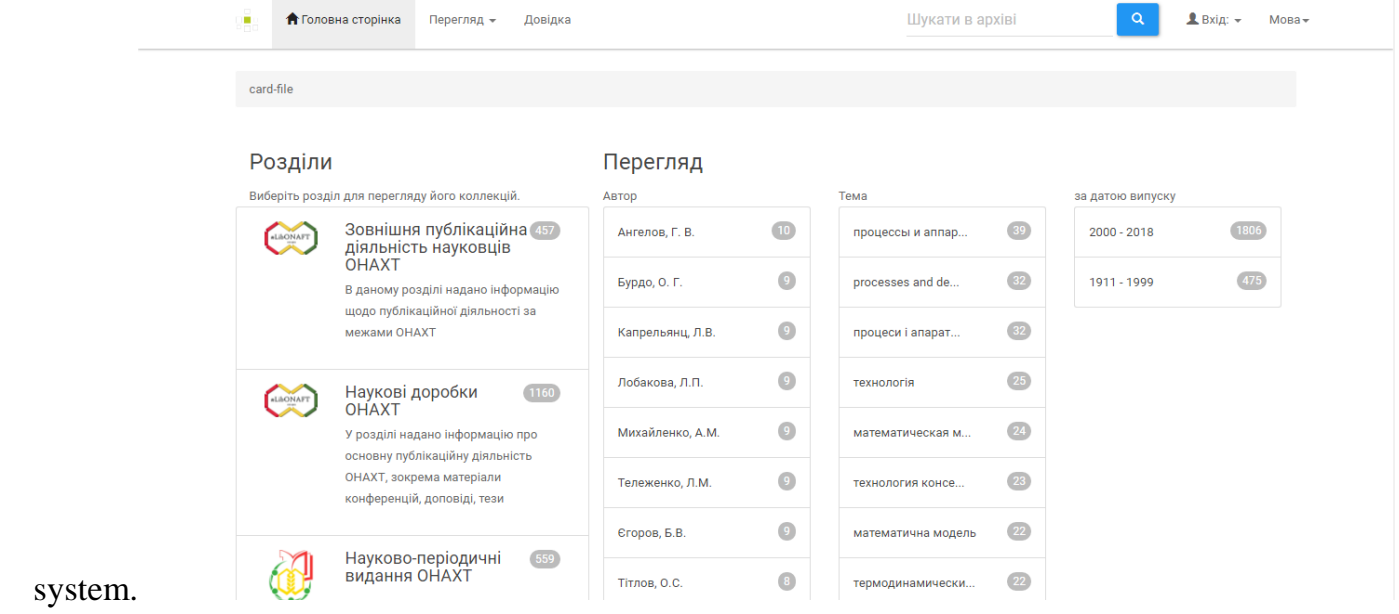

Fig. 2 - Odessa National Academy of Food Technologies Repository "card-file"

\section{Conclusions}

The implemented software product is based on the established list of requirements for the functional capabilities of the project. To develop the information management system for the library fund, a number of tasks were performed:

- $\quad$ selected research area;

- $\quad$ analyzed a number of existing analogues, revealed their main disadvantages;

- $\quad$ the basic requirements for a software product are formulated;

- $\quad$ fixed assets and methods of development were chosen;

- $\quad$ the database schema and the scheme of the application are developed;

- $\quad$ submitted in writing, explanation of the stages of development, justification of the selected means and methods of project implementation and the summary of the overall capacity of the developed software product;

- developed high-quality software that meets all the requirements and is ready for implementation in the functioning of the Academy.

It should be noted that a web application has been developed that implements free access to an institutional repository that contains a list of scientific papers, dissertations, abstracts, reports, multimedia, etc. The practical value of the results. The result of the development is the information and control system for the library fund, realized for the purpose of free access to research related to the development of a specific subject field, for further use in the educational process of the HIE. 


\section{References}

1. Y. M. Xvostenko, ‘nformacy`onnye texnology`y`v by`bly`otekax: dajdzhest-konspekt. Novosy`by`rsk: Novosy`b. gos. obl. nauch. b-ka, 2015.

2. L. A. Ly`tvy`nova, “Osnovni napryamy` dy`sertacijny`x doslidzhen`z bibliotekoznavstva za special`nistyu 27.00.03 - Kny`goznavstvo, bibliotekoznavstvo, bibliografoznavstvo / Suchasni problemy` diyal`nosti biblioteky` v umovax informacijnogo suspil`stva : materialy` tret’oyi naukovo-prakty`chnoyi konferenciyi,” in Osnovni napryamy`dy`sertacijny`x doslidzhen` z bibliotekoznavstva za special`nistyu 27.00.03 - Kny`goznavstvo, bibliotekoznavstvo, bibliografoznavstvo / Suchasni problemy`diyal’nosti biblioteky`v umovax informacijnogo suspil`stva : materialy` tret`oyi naukovo-prakty`chnoyi konferenciyi, L`viv: Vy`davny`cztvo L`vivs`koyi politexniky`, 2011, pp. 398-409.

3. "SQLite vs MySQL vs PostgreSQL: sravneny`e sy`stem upravleny`ya bazamy` dannyx,"SQLite vs MySQL vs PostgreSQL: sravneny`e sy`stem upravlenyya bazamy dannyx / DEVACADEMY. [Online]. Available: http://devacademy.ru/posts/sqlite-vs-mysql-vs-postgresql/. [Accessed: 10-Jul-2018].

4. "SQLite," Wikipedia, 10-Jan-2018. [Online]. Available: https://en.wikipedia.org/wiki/SQLite. [Accessed: 10Jul-2018].

5. V. Drach, "Sravneny`e sovremennыx SUBD," Domoj. [Online]. Available: http://drach.pro/blog/hitech/item/145-db-comparison. [Accessed: 10-Jul-2018].

6. "Integrovane seredovy`shhe rozrobky`." [Online]. Available: http://lektsii.com/1-36439.html. [Accessed: 15Apr-2018].

7. “Obzor platformы Eclipse - kak eë y’spol'zovat', Komp yuternble texnology y' dlya rabotbl, uchëbbl y' by`znesa. [Online]. Available: https://hightech.in.ua/content/art-eclipse-platform. [Accessed: 10-May-2018].

8. "NetBeans IDE - uny`versal’naya y`ntegry`rovannaya sreda razrabotky` pry`lozheny`j,” Komp yuternble texnology ‘’ dlya rabotbl, uchëbbl y` by znesa. [Online]. Available: https://hightech.in.ua/content/art-netbeans-ide. [Accessed: 10-Jan-2018].

9. “IntelliJ IDEA,”Wikipedia, 09-Jan-2018. [Online]. Available: https://ru.wikipedia.org/wiki/IntelliJ_IDEA. [Accessed: 10-Jan-2018].

10. Opy`sany`e produkta JetBrains IntelliJ IDEA - ITPRO.UA. [Online]. Available: https://itpro.ua/product/jetbrains-intellij-idea/?tab=description. [Accessed: 10-Jan-2018].

11. Sobesedovany`e po Java EE - Spring Framework (voprosbl y`otvetbl). Chast` 1. [Online]. Available: http://javastudy.ru/interview/jee-spring-questions-answers/. [Accessed: 18-Jan-2018].12. Wizardjedi, "wizardjedi/myspring-learning," GitHub. [Online]. Available: https://github.com/wizardjedi/my-spring-learning/wiki/Spring-security. [Accessed: 10-Jul-2018].
13. "Salt
(cryptography)," Wikipedia,
03-Jun-2018.
[Online].
Available:

https://en.wikipedia.org/wiki/Salt_(cryptography). [Accessed: 10-Jun-2018].

\section{Література}

1. Информационные технологии в библиотеках: дайджест-конспект / Новосиб. гос. обл. науч. б-ка; сост. Хвостенко И.М.; ред. Носова Н.П.; отв. за вып. Деев В.Г. Новосибирск: Изд-во НГОНБ, 2015. 90 с.

2. Литвинова Л.А. Основні напрями дисертаційних досліджень з бібліотекознавства за спеціальністю 27.00.03 - Книгознавство, бібліотекознавство, бібліографознавство / Сучасні проблеми діяльності бібліотеки в умовах інформаційного суспільства : матеріали третьої науково-практичної конференції, Львів, 29 вересня 2011 року / Видавництво Львівської політехніки. Львів, 2011. - С. 398-409.

3. SQLite vs MySQL vs PostgreSQL: сравнение систем управления базами данных // devacademy.ru: образовательный проект. URL: http://devacademy.ru/posts/sqlite-vs-mysql-vs-postgresql/.

4. SQLite // uk.wikipedia.org: вікіпедія. 2017. 16 лип. URL: https://uk.wikipedia.org/wiki/SQLite.

5. Сравнение современных СУБД// drach.pro. 2017. 30 мая. URL: http://drach.pro/blog/hi-tech/item/145-dbcomparison.

6. Іатегроване середовище розробки // lektsii.com. 2014. 3 груд. URL: http://lektsii.com/1-36439.html.

7. Обзор платформы Eclipse - как её использовать // hightech.in.ua URL: https://hightech.in.ua/content/arteclipse-platform.

8. NetBeans IDE - универсальная интегрированная среда разработки приложений // hightech.in.ua. URL: https://hightech.in.ua/content/art-netbeans-ide.
9. IntelliJ IDEA //
uk.wikipedia.org:
вікіпедія.
2018.
31 мая.
URL: https://ru.wikipedia.org/wiki/IntelliJ_IDEA.

10. JetBrains IntelliJ IDEA // itpro.ua: сайт компания «Ай Ти Про». URL: https://itpro.ua/product/jetbrainsintellij-idea/?tab=description.

11. Собеседование по Java EE - Spring Framework (вопросы и ответы). Ч. 1. // javastudy.ru. 2017.6 сент. URL: http://javastudy.ru/interview/jee-spring-questions-answers/. 
12. Общие сведения о Spring Security // github.com. 22 фев. 2013. URL: https://github.com/wizardjedi/myspring-learning/wiki/Spring-security.

13. Сіль (криптографія) // uk.wikipedia.org: вікіпедія. 2018. 28 квіт. URL: https://uk.wikipedia.org/wiki/\%D0\%A1\%D1\%96\%D0\%BB\%D1\%8C_(\%D0\%BA\%D1\%80\%D0\%B8\%D0\%BF\%D1\%82\%D 0\%BE\%D0\%B3\%D1\%80\%D0\%B0\%D1\%84\%D1\%96\%D1\%8F)

\title{
СИСТЕМА СТАБІЛІЗАЦІї КУРСУ МОРСЬКОГО СУДНА, ЧАСТКОВО-ІНВАРІАНТНА ДО ВІТРО-ХВИЛЬОВИХ НАВАНТАЖЕНЬ
}

\author{
Волянська Я. Б. ${ }^{1}$, Голіков В. В. ${ }^{2}$, Мазур О. М. ${ }^{3}$, Онищенко О. А. ${ }^{4}$, Шевченко В. А. \\ 1 - Національний університет кораблебудування імені адмірала Макарова, пр-т Героїв України, 9, Миколаїв, 54000, \\ Україна. \\ 2-5 - Національний університет «Одеська морська академія», вул. Дідрихсона, 8, Одеса, 65029, Україна. \\ ORCID: ${ }^{1} \underline{0000-0002-3010-1684} ;{ }^{2} \underline{0000-0002-4523-2311} ;{ }^{3} \underline{0000-0002-9316-288 X} ;{ }^{4} \underline{0000-0002-3766-3188}$; ${ }^{50000-0003-}$ \\ 3229-1909. \\ e-mail: 1 yanavolyanskaya@gmail.com; $\quad{ }^{2}$ volodymyr.golikov@fms.onma.edu.ua; $\quad 3$ rio.nuoma@gmail.com; 4 \\ oleganaton@gmail.com; ${ }^{5}$ vash4891@gmail.com.
}

Copyright (C) 2018 by author and the journal "Automation technologies and business - processes. This work is licensed under the Creative Commons Attribution International License (CC BY). http://creativecommons.org/licanses/by/4.0

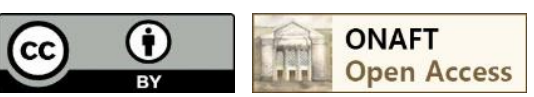

DOI: $10.15673 /$ atbp.v10i1.874

У статті показана можливість застосування у сучасних системах стабілізаџії курсу морського судна принципів частково-інваріантного керування до вітро-хвильових навантажень. Метою статті є встановлення можливостей підвищення точності стабілізації судна на заданому курсі $і$, відповідно, зниження витрати палива за рейс. Мета досягається за допомогою удосконалення алгоритму роботи автокермового. Запропоновано структурну схему двоканальної системи керування, щчо дозволяє: а) виділити точку прикладання основного навантаження; б) провести оцінку впливу, що збурює; в) сформувати передатну функиію коригуючої ланки позитивного зворотного зв'язку за допомогою додаткового каналу керування. Частково-інваріантну систему керування синтезовано на основі спрощеної математичної моделі динаміки судна - моделі Номото другого порядку і ПІД-регулятора, налаштованого на технічний оптимум у припущенні, щьо результуюче навантаження приведено до кута повороту керма. Основна відмінність запропонованої системи керування укладена у використанні принципу непрямої оцінки й виміру збурення за рахунок обробки інформаційних сигналів итатних датчиків судна і його навігаційно-вимірювальної системи. Результат роботи запропонованої системи керування ілюструється математичним моделюванням системи стабілізації курсу морського судна криголамного типу. Моделювання проведено засобами MatLab/Simulink при стрибкоподібних вітро-хвильових навантаженнях, щуо суттєво відхиляють курс судна від заданого значення. При аналізі динаміки запропонованої системи керування використано математичний опис судна, отриманий методами ідентифікації параметрів нелінійної моделі Номото другого порядку. У результаті встановлено, щчо запропонована система має суттєво кращі динамічні властивості - час входження у зону стабілізації $і$ максимальне динамічне відхилення знижуються, приблизно, у 8 разів при умові, щүо обмеження рівня сигналів у системі відсутнє.

Ключові слова: інваріантний, збурення, система керування, автокермовий, курсовий кут, математична модель, динаміка судна. 